\title{
O2O Iterative Project-based Teaching Model for Literature Course
}

\author{
https://doi.org/10.3991/ijet.v15i16.15711 \\ Yin Dai \\ Chongqing Vocational Institute of Tourism, Qianjiang, China \\ lunwen3215@126.com
}

\begin{abstract}
As a main course of Chinese language and literature major in colleges, Literature Course is one of required courses for students majoring in journalism, hosting and broadcasting, which can cultivate students' favorable humanistic quality and promote their specialty development. However, some problems exist in traditional teaching process, such as low interest in linguistics, insufficient interaction between teachers and students, and single evaluation system. Starting from Merrill's chief teaching principle and aiming at teaching deficiencies of Literature Course, this study innovatively introduced $\mathrm{O} 2 \mathrm{O}$ iterative project-based teaching model to establish an iterative teaching model based on online and offline integration. In combination of the question-based teaching method, four teaching steps including "construction, guidance, tutoring and introspection" were designed under the cooperation of $\mathrm{O} 2 \mathrm{O}$ space environment and collaborative mechanism, and a brand-new implementation framework for linguistics teaching was tentatively constructed. To test the effect of this teaching mode, classification and regression tree (CART) algorithm of data mining technology was applied to compare and evaluate teachers' teaching ability before and after the implementation of this teaching mode. It is found that, this teaching reform contributes to cultivating students' critical thinking and innovation ability, and enhancing their academic research spirit and ability of language theory application.
\end{abstract}

Keywords-O2O iterative project; evaluation; classification and regression tree algorithm; blended teaching.

\section{$1 \quad$ Introduction}

Literature will influence human behavior and mentality, improve human thoughts and feelings, and enhance human confidence in life. The setup of Literature Course can make students feel richness, profundity, purity, facticity and universality of literature, and help update students' cognition of life [1]. Literary education is also an important part of college general education. But there are still some shortcomings in teaching Literature Course, mainly because "cramming education" is usually adopted for this course for a long time [2]. The teacher unilaterally decides the teaching method, teaching objective, teaching process implementation and teaching content design, and students fail to give play to their initiative. As a result, the whole teaching 
process becomes "sole show" of the teacher, and students show poor interest and initiative [3]. Besides, students need to experience deeply and participate in Literature Course. In other words, students' initiative will directly influence the teaching effect of Literature Course. Thus, college teachers must seek a more effective and scientific teaching model in order to improve the teaching effect of Literature Course, cultivate students' literary connotation and enhance their literature quality. On this basis, $\mathrm{O} 2 \mathrm{O}$ iterative project-based teaching model which is now applied college information teaching was chosen for teaching practice and reform to investigate its design and application in college Literature Course and offer suggestions for the implementation of Literature Course teaching. Compared with previous teaching methods of Literature Course teaching, this study, on the one hand, introduces $\mathrm{O} 2 \mathrm{O}$ iterative project-based teaching model and provides a new thought for Literature Course teaching; on the other hand, it develops teaching's ability evaluation system for $\mathrm{O} 2 \mathrm{O}$ iterative project-based teaching model to evaluate and feedback teachers' ability in time.

\section{State of the Art}

Literature-related courses are difficult to teach, so some pedagogy scholars' study how to enhance the teaching effect and improve the teaching method of this course. Europe, America and other developed countries are the birthplaces where Literature Course is included in general education, and relevant theories and practice are mature there. For example, Harvard University attaches great importance to learning literature courses, and proposes Literature Course plays a critical role in achieving its talent training objective. Omar [4] holds that students' ability of thinking should be mainly cultivated in Literature Course. He constructed the i-Think project which is composed of eight cognitive teaching tools. The result shows that teachers can improve students' critical thinking ability by using the mind mapping of i-Think project in literature class. Elhamr [5] et al. aimed to recognize the biggest obstacles for English literature teaching from the perspective of male and female teachers at The University of Hail $(\mathrm{UoH})$. The data analysis demonstrates that students' language level, discourse language, literary form difficulty and cultural familiarity are key problems influencing the process of teaching and learning Literature Course, and that students' independent reading is an effective way to improve the teaching effect of Literature Course. Meanwhile, many scholars studied how to utilize the advantage of information technology for course teaching, which provides a theoretical foundation for Literature Course teaching. For instance, Zamansky \& Farchi [6] combined course teaching status based on information technology and considered that the blended teaching method also should pay attention to structuration \& non-structuration, tradition \& network, existing content \& customized content, and customized pace \& real-time cooperation, except online and offline combination, to promote the teaching effect. Colleges should fully pay attention to students' actual needs in course teaching, fully cognize the essence of course teaching and give performance support. On this basis, the author proposed to a blended teaching method which combines offline and 
online teaching. Paiva et al. [7] held that, among the numerous course teaching methods, the blended teaching method is student-centered and also integrates all kinds of learning resources. Finally, it stimulates learners with a strategy to actively seek an optimal learning method.

Literature Course has been taught with traditional teaching method, so some teaching problems exist, such as poor learning initiative and insufficient teaching resources. Based on this, the research on teaching methods and teaching design of Literature Course is increasing. Literature Course teaching in college general education starts late, and it is still in the stage of learning, reference and exploration. For example, Liu [8] started from Ancient Literature to explore practical teaching methods available and offered the reference for the research on Literature Course Teaching method. Through the study, the author considered that college teachers could improve teaching effect of Ancient Literature and practically enhance students' humanistic quality and specialized knowledge through scene teaching, heuristic teaching, research teaching and lecture teaching. Based on the practical teaching experience of Modern and Contemporary Literature, Lv [9] considered that, innovation should be valued in Literature Course teaching, and college education workers should change their teaching ideas, and fully combine students' learning level and market demand for talents to introduce relevant teaching resources. In the meantime, the author thought that, it is necessary to improve practical teaching system and ensure the successful implementation of Literature Course teaching in the teaching process.

With the rapid development of internet information technology, the blended teaching mode is applied in many courses, including Literature Course. Many scholars also conducted relevant research. For instance, Zhang et al. [10] took Literature Course of School of Literature, Inner Mongol University for Nationalities for example and analyzed the specific application of blended teaching model in detail. In addition, they used the blended teaching model to design Literature Course, then analyzed the application of blended teaching model from three aspects (before class, in class and after class) and believed that the blended teaching model not just gives play to teacher's guiding role, but also improves students' autonomous learning ability and learning efficiency of Literature Course. Moreover, they also mentioned the application of blended teaching method in examination evaluation. $\mathrm{Wu}$ [11] investigated the new blended teaching method based on the blended teaching theory by taking college Literature Course teaching for example, and held that, compared with traditional Literature Course teaching, the blended teaching method combines students' autonomous learning and collaborative learning, and also adopts the evaluation model of outcome assessment and process evaluation, which improves students' learning initiative and could practically help teachers understand students' actual needs. At the same time, some scholars discovered some defects of blended teaching method. For instance, Wang [12] discovered that the blended teaching model is restricted to students' autonomous learning motivation, and leads to students' fragmented learning. Furthermore, the problems of online learning deficiency and the difficulty in well connecting online and offline learning may easily occur. 
Based on the above studies, many scholars have carried out relevant research on Literature Course teaching. The teaching mode of Literature Course changes to the blended online and offline teaching model from traditional offline teaching model. Such teaching mode fully mobilizes students' initiative, so its teaching effect is better. Nevertheless, it is difficult to teach Literature Course, and many teaching resources are required. Besides, student differences may be larger, and the effect of blended teaching model largely depends on students' autonomic learning. It is hard to effectively connect online and offline learning. Thus, pure blended teaching mode is difficult to meet the demand of Literature Course teaching in the current stage. On this basis, this study tries to integrate blended teaching and iterative teaching, namely, applying $\mathrm{O} 2 \mathrm{O}$ iterative project-based teaching method for Literature Course design. Additionally, to test the application effect of $\mathrm{O} 2 \mathrm{O}$ iterative project-based teaching model in Literature Course, teacher's teaching ability was evaluated with CART algorithm in data mining to further improve the teaching level of Literature Course.

\section{$3 \quad$ O2O Iterative Project-Based Teaching Model}

\subsection{O2O iterative project-based teaching model based on blended teaching}

$\mathrm{O} 2 \mathrm{O}$ iterative project-based teaching is an iterative teaching mode which depends on online and offline $(\mathrm{O} 2 \mathrm{O})$ integration. Its basic idea is shown in Fig.1:

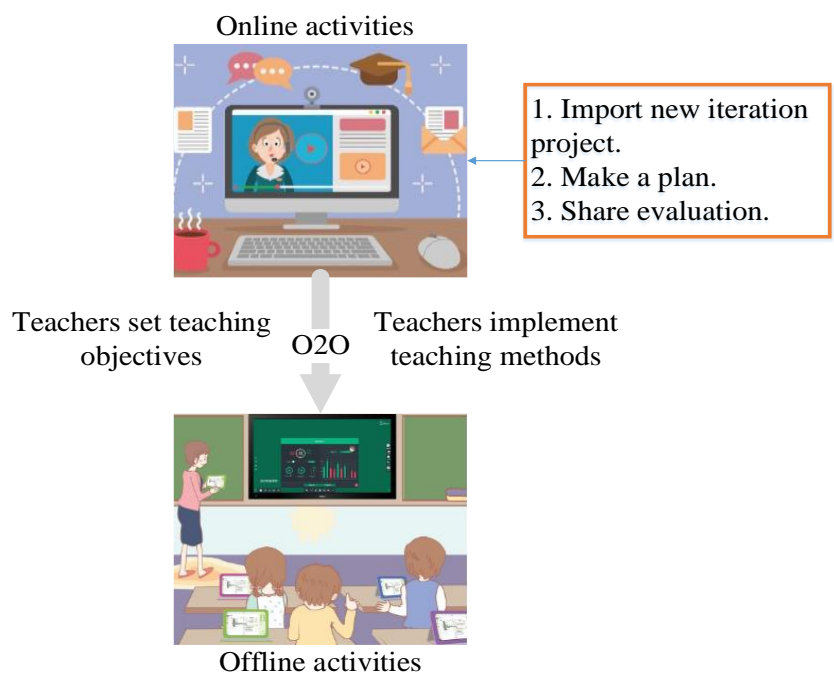

Fig. 1. O2O iterative project-based teaching model

$\mathrm{O} 2 \mathrm{O}$ iterative project-based teaching model is mainly the iteration of online and offline activities. Online activity indicates "need to know what to do", and offline activity indicates "need to know how to do". In the course learning, after learners clearly know relevant information which needs to be mastered offline, they will 
actively learn online in "need to know". After mastering relevant indications, learners will challenge offline "need to do". It thus can be seen that, online activity is closely related to offline activity, and it will appear repeatedly after learners master complex content. Such repeatability is the process of decomposing complex knowledge into multiple small functional iteration items, thus achieving the final learning objective step by step.

Project-based learning (PBL) is a research-style teaching model for complex situation problems. Due to the complexity of Literature Course, O2O iterative projectbased teaching model should be based on PBL. Taking literature story situation in Literature Course for example, PBL-based $\mathrm{O} 2 \mathrm{O}$ iterative project-based teaching model is shown in Fig.2:

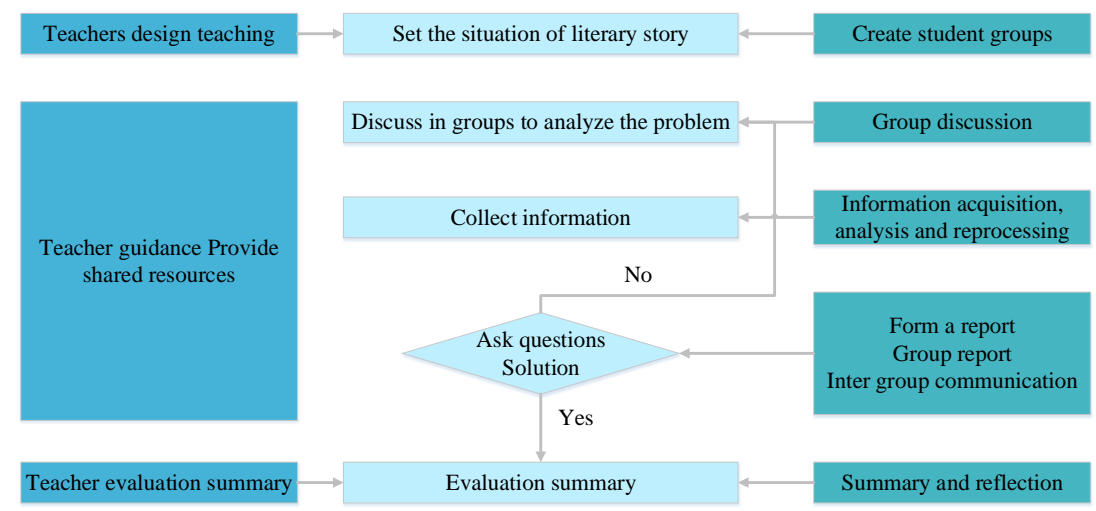

Fig. 2. PBL-based $\mathrm{O} 2 \mathrm{O}$ iterative project-based teaching model

In the PBL-based O2O iterative project-based teaching model, Literature Course teaching can be divided into five parts: literature story situation setting, group discussion, information collection, problem solution proposing and evaluation \& summarization. In literature story situation setting, student groups need to create the situation according to their preferences. On this basis, the teacher extracts and designs. Group discussion, information collection and problem solution proposing are completed in groups, and students need $\mathrm{O} 2 \mathrm{O}$ iterative learning. The teacher guides and offers shared resources in the process. If the solution proposed can resolve the problem, students can enter the evaluation \& summarization step, or else they will enter the group discussion step again. Thus, both the teacher and students should cooperate in the PBL-based $\mathrm{O} 2 \mathrm{O}$ iterative project-based teaching model, in which students are the main players and the teacher is a guide. Such mode mobilizes students' participation enthusiasm through a story situation.

\subsection{Design mode of $\mathbf{O 2 O}$ iterative project-based teaching model integrated with chief teaching principle for Literature Course}

Based on the understanding of $\mathrm{O} 2 \mathrm{O}$ iterative project-based teaching model based on blended teaching, the chief teaching principle is integrated in this part to design 
O2O iterative project-based teaching model based on blended teaching for Literature Course. For the overall teaching function of Literature Course, the module design is shown in Fig.3:

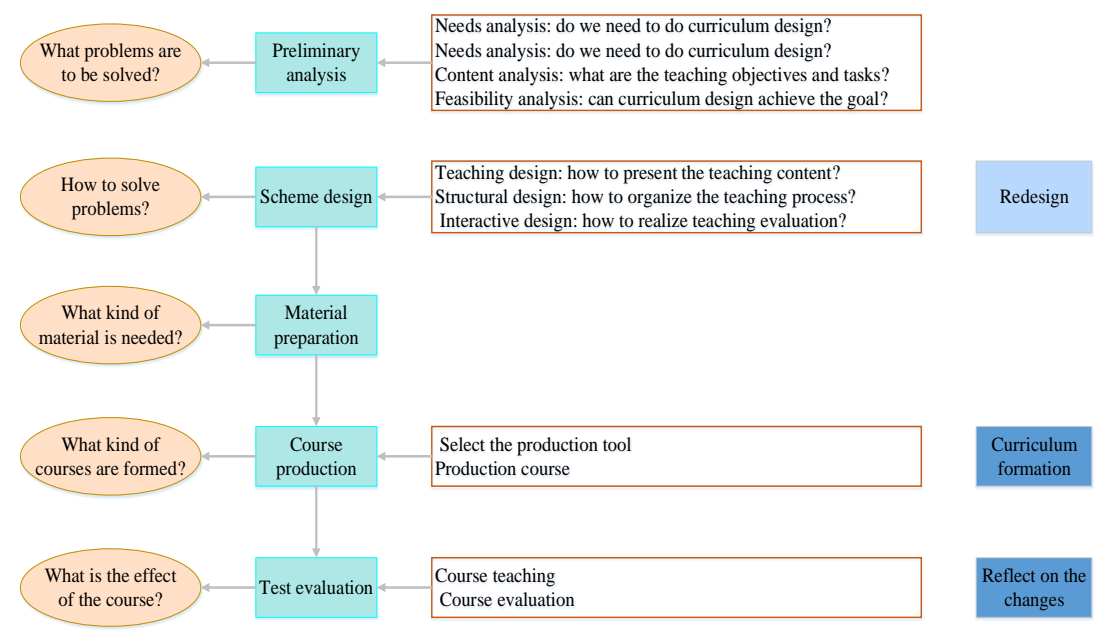

Fig. 3. Teaching function module design of Literature Course

The chief teaching principle is to cultivate learners' ability to solve problems through explanation, question asking, exhibition and operation for different knowledge and principles. $\mathrm{O} 2 \mathrm{O}$ iterative project-based teaching model based on this principle is to decompose a complex project into multiple small function items with relevant knowledge, then go forward layer upon layer in the mode of iterative sequence and solve problems step by step. According to Fig.3, in this teaching model, the teaching function of Literature Course is divided into five steps: preliminary analysis, program design, material preparation, course making and test $\&$ evaluation. "Learning" stage corresponds to "teaching" stage in the chief teaching principle, and the two are connected through "construction, guidance, tutoring and introspection".

In the numerous teaching function modules, the teaching model function module is of great importance. Hence, teaching model function module of $\mathrm{O} 2 \mathrm{O}$ iterative projectbased teaching model was designed based on the chief teaching principle. The design results are shown in Fig.4: 


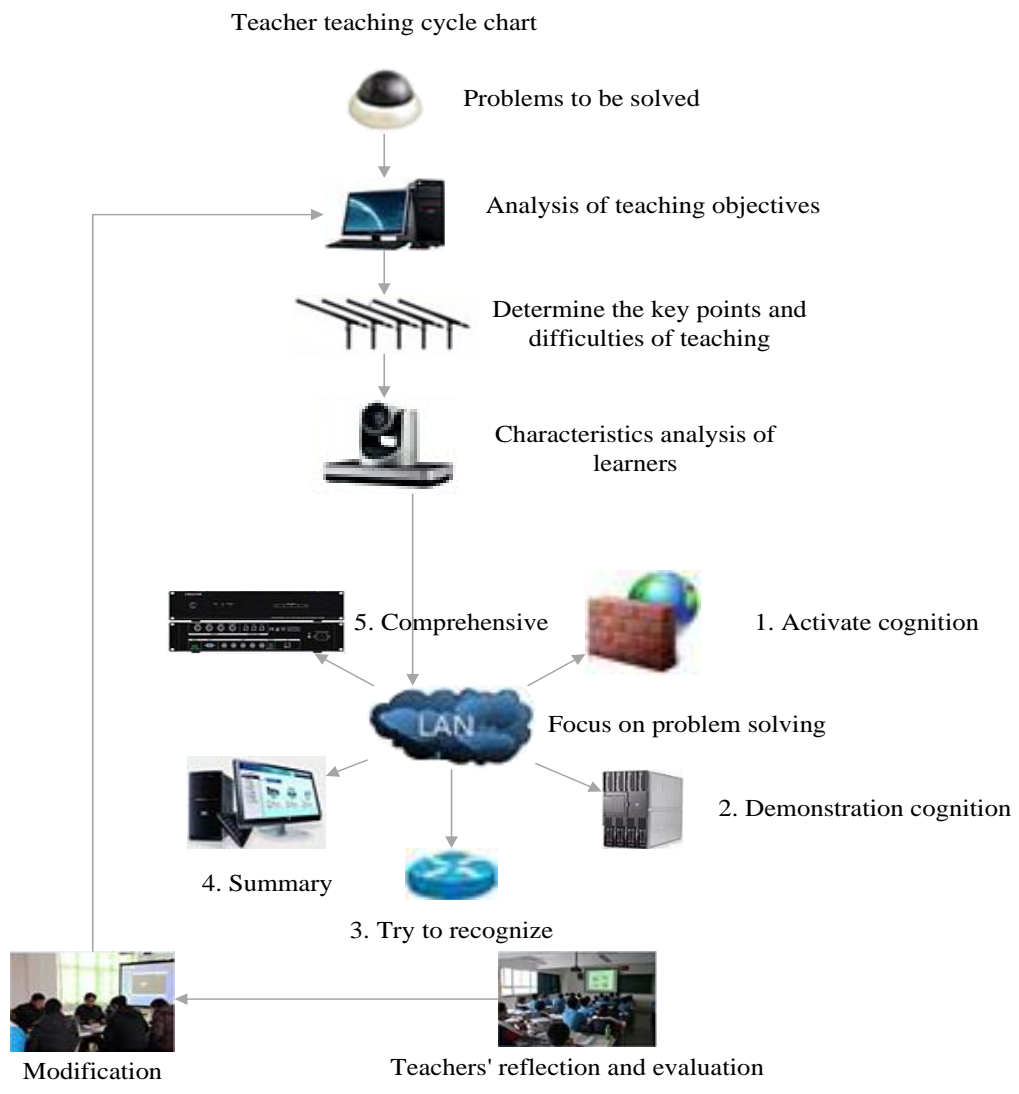

Fig. 4. Teaching model function module of Literature Course

According to teaching model function module of Literature Course in Fig.4, Literature Course teaching can be divided into the following steps: "activating old knowledge structure", "guiding to form new knowledge structure", "tutoring the application of new knowledge structure", "summarizing and concluding", and "digesting". The whole process is centered with "focusing on solving problems" to form a teaching circle. In addition, there is also a very important step in the design of teaching model function of Literature Course, i.e. test $\&$ evaluation which is also an important content of Literature Course design and aims to optimize teaching design.

\subsection{Teacher's ability evaluation of Literature Course based on O2O iterative project-based teaching model}

Both the teaching function module of Literature Course and specific teaching model function module need the teacher's introspection and evaluation. Thus, teacher's ability evaluation system of Literature Course based on $\mathrm{O} 2 \mathrm{O}$ iterative project-based teaching model was designed. To be specific, data mining technology 
will be used for evaluation. This study referred to relevant practice of Zhang Ling (2018), and adopted CART algorithm in decision tree algorithm.

\section{Definition of Gini index}

CART algorithm usually adopts Gini index as a standard for division, and the Gini index is as below:

$$
\operatorname{Gini}(D)=1-\sum_{k=1}^{N} P_{k}^{2}
$$

Wherein, ${ }^{p_{k}}$ is the proportion of the kth sample. Usually, when the samples are uniform, Gini index is large. During teacher evaluation, the minimum Gini index was chosen for division, because the minimum Gini index can distinguish specific attribute of samples to a large extent.

Wherein, the computational formula of Gini index of attribute a is as below:

$$
I_{G}(f)=\sum_{i=1}^{m} f_{i}\left(1-f_{i}\right)=\sum_{i=1}^{m}\left(f_{i}-f_{i}^{2}\right)=1-\sum_{i=1}^{m} f_{i}^{2}
$$

\section{Determination of classification tree}

For the same set $\mathrm{S}$, the calculation of Gini index is as below:

$$
\operatorname{Gini}(S)=1-\sum_{k=1}^{N} P_{k}^{2}
$$

There are $\mathrm{N}$ samples in the sample set $\mathrm{S}$. If the ith attribute value of Attribute $\mathrm{A}$ is used as the standard, the whole sample set will be divided into two subsets. At this time, Gini index is calculated as below:

$$
\operatorname{Gain}_{-} \operatorname{Gini}_{A, i}(S)=\frac{n_{1}}{N} \operatorname{Gini}\left(S_{1}\right)+\frac{n_{2}}{N} \operatorname{Gini}\left(S_{2}\right)
$$

Next, the optimal value of the divided Gini index is solved,

$$
\min _{i \in A}\left(\operatorname{Gain}_{-} \operatorname{Gini}_{A, i}(S)\right)=\min _{i \in A}\left(\frac{n_{1}}{N} \operatorname{Gini}\left(S_{1}\right)+\frac{n_{2}}{N} \operatorname{Gini}\left(S_{2}\right)\right)
$$

On this basis, the optimal dichotomy scheme of the whole sample set $\mathrm{S}$ forms, i.e.

$$
\min _{\text {A Atribute }}\left(\min _{i \in A}\left(\text { Gain__Gini }_{A, i}(S)\right)\right)
$$

\section{Determination of regression number}

For the sample set $\mathrm{S}$ with continuous prediction results, its total variance is 


$$
\sigma(S)=\sqrt{\sum\left(y_{k}-\mu\right)^{2}}
$$

Similarly, there are $\mathrm{N}$ samples in the sample set $\mathrm{S}$. If the ith attribute value of Attribute A is used as the standard, the Gini index is calculated as below:

$$
\text { Gain_ } \sigma_{A, i}(S)=\sigma\left(S_{1}\right)+\sigma\left(S_{2}\right)
$$

The optimal dichotomy scheme of attribute $\mathrm{A}$ is

$$
\min _{i \in A}\left(\text { Gain_} \sigma_{A, i}(S)\right)=\min _{i \in A}\left(\sigma\left(S_{1}\right)+\sigma\left(S_{2}\right)\right)
$$

The optimal dichotomy scheme of the whole sample set $\mathrm{S}$ is

$$
\min _{\text {A Atribute }}\left(\min _{i \in A}\left(\text { Gain }_{-} \sigma_{A, i}(S)\right)\right)
$$

In combination of teaching situation of Literature Course, teacher's teaching ability evaluation system involves 5 primary indexes (including basic quality of teaching, classroom teaching ability, capacity for scientific research, literature specialty ability

\begin{tabular}{|c|c|}
\hline Primary index & Secondary index \\
\hline Basic quality of teaching (A1) & $\begin{array}{l}\text { 1. Proficiency test } \\
\text { 2. The highest academic degree } \\
\ldots .5 \text { items in total }\end{array}$ \\
\hline Classroom teaching ability (A2) & $\begin{array}{l}\text { 1. Highlight key points in classroom } \\
\text { 2. Teaching plan preparation for Literature Course } \\
\text {.....11 items in total }\end{array}$ \\
\hline $\begin{array}{l}\text { Capacity for scientific research } \\
\text { (A3) }\end{array}$ & $\begin{array}{l}\text { 1. Awards for teaching research } \\
\text { 2. Teaching research paper publishing } \\
\text {....6 items in total }\end{array}$ \\
\hline Literature specialty ability (A4) & $\begin{array}{l}\text { 1. Awards for scientific research } \\
\text { 2. Professional certificate holding } \\
\text {.....7 items in total }\end{array}$ \\
\hline After-class tutoring ability (A5) & $\begin{array}{l}\text { 1. Homework assigning } \\
\text { 2. Assignment tutoring .....5 items in total }\end{array}$ \\
\hline
\end{tabular}
and after-class tutoring ability) and 34 secondary indexes. The specific construction of teacher's teaching ability evaluation indexes is as below:

Table 1. Teacher'ss teaching ability evaluation system of Literature Course

Based on the data mining results of CART algorithm in the decision tree algorithm, the index weight results are shown in Table 2: 
Table 2. Index weight results

\begin{tabular}{|c|c|c|c|}
\hline Primary index & $\begin{array}{c}\text { Primary index } \\
\text { weight }\end{array}$ & Secondary index & $\begin{array}{c}\text { Secondary } \\
\text { index weight }\end{array}$ \\
\hline $\begin{array}{l}\text { Basic quality of } \\
\text { teaching (A1) }\end{array}$ & 0.04 & $\begin{array}{l}\text { 1. Proficiency test (B1) } \\
\text { 2. The highest academic degree (B2) } \\
\text {....5 items in total }\end{array}$ & $\begin{array}{l}0.12 \\
0.05 \\
\ldots \ldots\end{array}$ \\
\hline $\begin{array}{l}\text { Classroom } \\
\text { teaching ability } \\
\text { (A2) }\end{array}$ & 0.32 & $\begin{array}{l}\text { 1. Highlight key points in classroom (B6) } \\
\text { 2. Teaching plan preparation for Literature } \\
\text { Course (B7) } \\
\ldots \ldots 11 \text { items in total }\end{array}$ & $\begin{array}{l}0.26 \\
0.12 \\
\ldots \ldots\end{array}$ \\
\hline $\begin{array}{l}\text { Capacity for } \\
\text { scientific } \\
\text { research (A3) }\end{array}$ & 0.14 & $\begin{array}{l}\text { 1. Awards for teaching research (B17) } \\
\text { 2. Teaching research paper publishing (B18) } \\
\text {.....6 items in total }\end{array}$ & $\begin{array}{l}0.11 \\
0.09 \\
\ldots \ldots\end{array}$ \\
\hline \begin{tabular}{|l|} 
Literature \\
specialty ability \\
(A4)
\end{tabular} & 0.22 & $\begin{array}{l}\text { 1. Awards for scientific research (B23) } \\
\text { 2. Professional certificate holding (B24) } \\
\text {.....7 items in total }\end{array}$ & $\begin{array}{l}0.07 \\
0.14 \\
\ldots \ldots\end{array}$ \\
\hline \begin{tabular}{|l|} 
After-class \\
tutoring ability \\
(A5)
\end{tabular} & 0.28 & $\begin{array}{l}\text { 1. Homework assigning (B30) } \\
\text { 2. Assignment tutoring (B31) } \\
\text {.....5 items in total }\end{array}$ & $\begin{array}{l}0.11 \\
0.19 \\
\ldots \ldots\end{array}$ \\
\hline
\end{tabular}

It is assumed that teacher's second-level score of Literature Course is shown in Table 3, and teacher's teaching ability evaluation result of the course can be gained.

Table 3. Teachers teaching ability evaluation result of a literature course

\begin{tabular}{|l|c|c|c|c|c|c|}
\hline & A1 (0.04) & A2 (0.32) & A3 (0.14) & A4 (0.22) & A5 (0.28) & Comprehensive \\
\hline Score & 91 & 89 & 96 & 93 & 82 & 88.98 \\
\hline
\end{tabular}

\section{Teaching Example and Effect}

\subsection{Teaching example}

Based on the above analysis results, practical teaching case was used to further learn about the application of $\mathrm{O} 2 \mathrm{O}$ iteration in Literature Course. Taking works appreciation in Literature Course for example, $\mathrm{O} 2 \mathrm{O}$ iterative project-based teaching model is shown in Fig.5: 


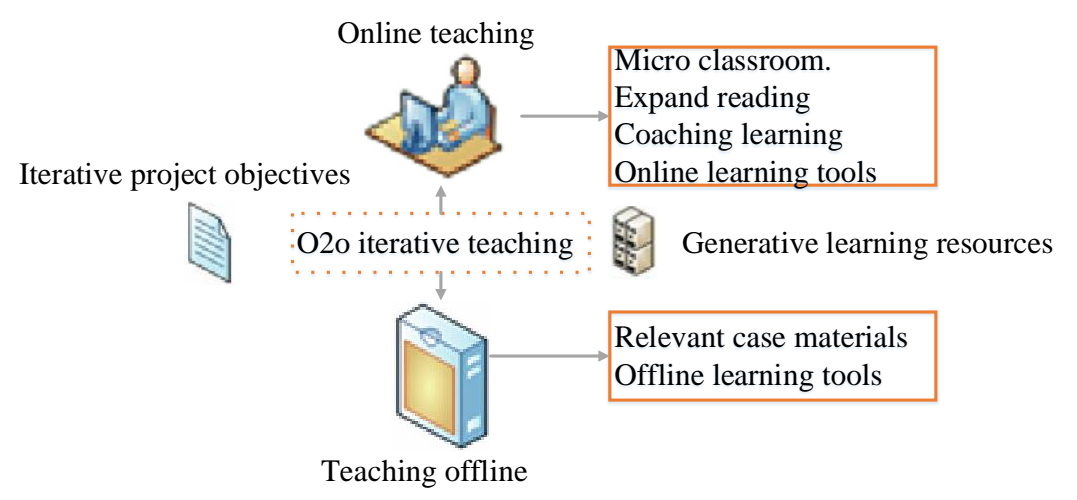

Fig. 5. Application case of $\mathrm{O} 2 \mathrm{O}$ iterative project-based teaching model in works appreciation

It can be seen from the application case that, $\mathrm{O} 2 \mathrm{O}$ iterative project-based teaching model fully combines online and offline teaching in works appreciation. College students cannot just apply various online resources and tools, but also match "generative resources", "case materials" and "Offline learning tool" modules to feel relevant works in offline classroom environment. Thus, $\mathrm{O} 2 \mathrm{O}$ iterative project-based teaching model gives full play to the teacher's guiding role and students' initiative. Fig. 6 shows a project-based teaching scene.

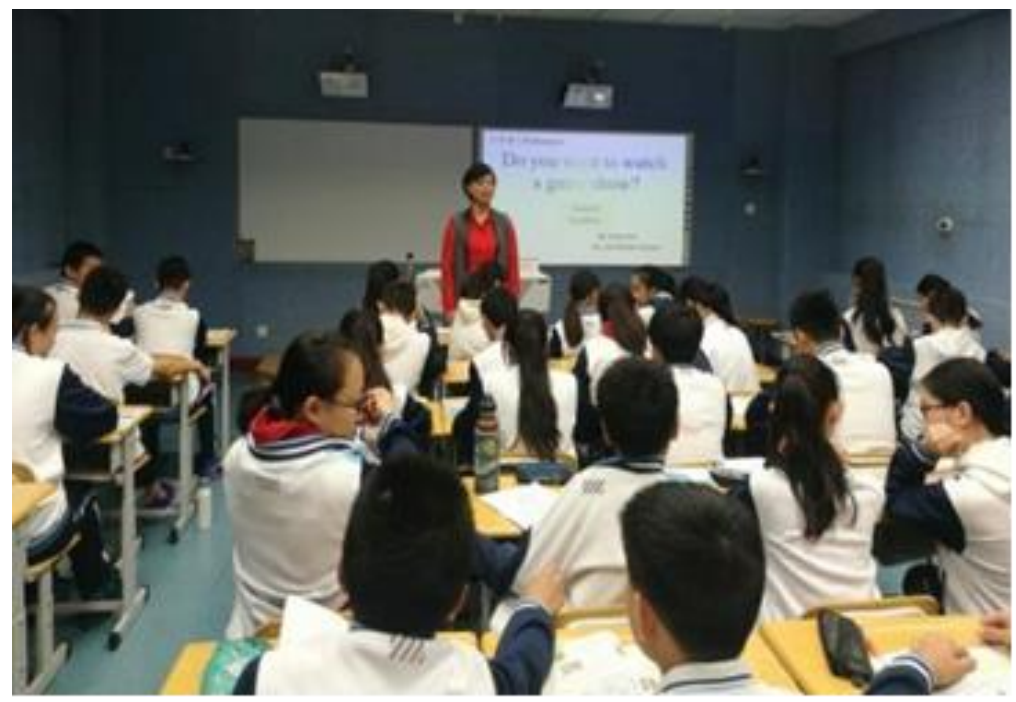




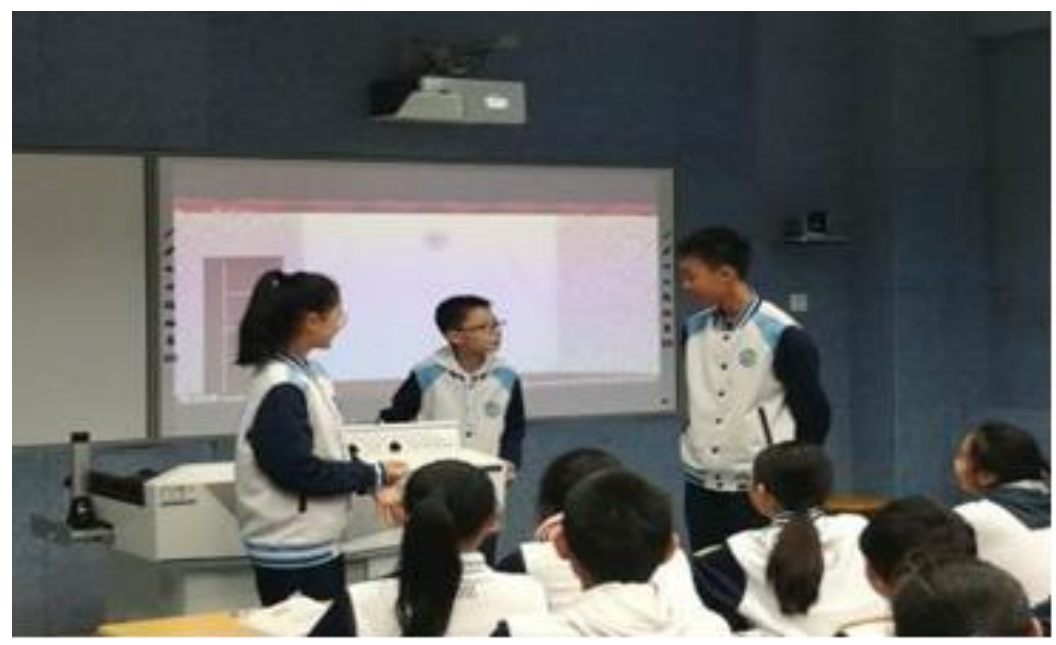

Fig. 6. Project-based teaching scene (https://www.sohu.com/a/270165944_732102)

According to Fig.6, a special teaching model of project-based teaching method can be applied, that is, students act as the teacher, and the teacher serves as a teaching assistant. The classroom is divided into four teacher-student interaction modules. In the teaching process, the teacher needs to discuss and solve problems together with students, and electronic teaching material or other text materials can be introduced to assist teaching.

\subsection{Teaching effect}

To test the effect of $\mathrm{O} 2 \mathrm{O}$ iterative teaching model, control group and observation control were designed in this study. The above-mentioned teacher's teaching ability evaluation system was used to assess teacher's teaching ability, students' learning initiative and interest in the control group and Experimental group. $\mathrm{O} 2 \mathrm{O}$ iterative teaching model was not applied for the Experimental during teaching works appreciation, while it was adopted for the Control group. The detailed scores are shown in Table 4:

Table 4. Comparison of performance evaluation of students in art course

\begin{tabular}{|l|c|c|c|c|}
\hline & Learning initiative & Learning interest & $\begin{array}{c}\text { Teacher's teaching } \\
\text { ability }\end{array}$ & Total score \\
\hline Control group $(\mathrm{n}=115)$ & $23.21 \pm 3.09$ & $26.77 \pm 1.29$ & $51.67 \pm 2.88$ & $101.65 \pm 7.26$ \\
\hline Experimental $(\mathrm{n}=123)$ & $24.16 \pm 4.11$ & $27.19 \pm 2.00$ & $72.91 \pm 1.42$ & $124.26 \pm 7.53$ \\
\hline $\mathrm{t}$ & -3.187 & -4.192 & -3.090 & -4.094 \\
\hline $\mathrm{P}$ & 0.002 & 0.000 & 0.005 & 0.000 \\
\hline
\end{tabular}

It can be seen from Table 4 that, after $\mathrm{O} 2 \mathrm{O}$ iterative teaching model was used, students' learning initiative and interest improved significantly at the significance level of 5\%. Meanwhile, teacher's teaching ability also was enhanced obviously. 


\section{Conclusion}

Based on $\mathrm{O} 2 \mathrm{O}$ iterative project-based teaching in which the theories of chief teaching principle and CART algorithm are integrated, this study combined actual situations of college Literature Course to design $\mathrm{O} 2 \mathrm{O}$ iterative project-based teaching module in which chief teaching principle is integrated, and $\mathrm{O} 2 \mathrm{O}$ iterative projectbased teaching model module in which chief teaching principle is integrated. Besides, based on CART algorithm of data mining, the teacher's evaluation system for Literature Course was established. The following conclusions can be drawn through the study:

1. $\mathrm{O} 2 \mathrm{O}$ iterative project-based teaching in which chief teaching principle is integrated mainly decomposes a complex project gradually into multiple small function items with relevant knowledge, then goes forward layer upon layer in the form of iterative sequence and solves problems step by step.

2. $\mathrm{O} 2 \mathrm{O}$ iterative project-based teaching in which chief teaching principle is integrated mainly involves the following steps: "activating old knowledge structure", "guiding to form new knowledge structure", "tutoring the application of new knowledge structure", "summarizing and concluding", and "digesting". The whole process is a teaching circle, which aims to solve core problems.

3. $\mathrm{O} 2 \mathrm{O}$ iterative project-based teaching model significantly improves the teaching effect of college Literature Course, which is specifically reflected in the significant improvement of students' learning initiative and interest as well as teacher's teaching ability.

\section{References}

[1] Shang, W. Construction and application of wechat learning platform in "folk literature" teaching. International Journal of Emerging Technologies in Learning, 2016, vol. 11(5), pp. 10-15. https://doi.org/10.3991/ijet.v11i05.5688

[2] Macke, C., \& Tapp, K. Teaching research to msw students: effectiveness of the team-based learning pedagogy. Journal of Teaching in Social Work, 2012, vol. 32(2), pp. 148-160. https://doi.org/10.1080/08841233.2012.668161

[3] Li, M.L., \& Ren, Y.J. A multimedia teaching model for "sports statistics" based on arcs motivation theory. International Journal of Emerging Technologies in Learning, 2018, vol. vol. 13(9), pp. 15-28. https://doi.org/10.3991/ijet.v13i09.8972

[4] Omar, A., Albakri, I.S.M.A. Thinking Maps to Promote Critical Thinking through the Teaching of Literature in the ESL Context. 2016, vol. 1(1), pp. 23-35. https://doi.org/10.21 093/ijeltal.v1i1.6

[5] Elham, T.H., \& Aida, H. A. Challenges to teaching English Literature at the university of hail: instructors' perspective. social science electronic publishing. 2017, vol. 7(4), pp. 125128.

[6] Zamansky, A., Farchi, E. Teaching Logic to Information Systems Students: Challenges and Opportunities. computer science, 2015, vol. 42(3), pp. 359-368.

[7] Paiva, R.C., Ferreira, M.S., Frade, M.M. Intelligent tutorial system based on personalized system of instruction to teach or remind mathematical concepts. Journal of Computer 
Assisted Learning, 2017, vol. 33(4), pp. 370-381. https://doi.org/10.1111/jcal.12186

[8] Liu, X.S. On Teaching Methods of Ancient Chinese Literature. Course Education Research, 2016, vol. 18(3), pp. 46-47.

[9] Lv, X.M. On the current situation and Countermeasures of practical teaching of modern and Contemporary Literature. Education Teaching Forum, 2012, vol. 25(4), pp. 111-113.

[10] Zhang, L.L., Hua, Z.Q., Yu, B.J. et al. The application of mixed learning mode in the teaching reform of modern Chinese Literature. Kaoshi Zhoukan, 2017, vol. 24(9), pp. 3940

[11] Jin, Z.S. The role of teachers and the construction of learning model of literature courses based on Hybrid Learning. University Education, 2013, vol. 31(1), pp. 105-106.

[12] Yu, W., Ren, W.N., Zhang, J. The exploration and practice of how to improve students' learning engagement in Hybrid Teaching. Human Resource Management, 2017, vol. 36(5), pp. 200-201.

\section{Author}

Yin Dai is a Lecturer in the Chongqing Vocational Institute of Tourism, qianjiang, China (lunwen3215@126.com).

Article submitted 2020-05-23. Resubmitted 2020-07-05. Final acceptance 2020-07-07. Final version published as submitted by the authors. 